\title{
BEYOND "IT JUST AIN'T WORTH IT": ALTERNATIVE STRATEGIES FOR DAMAGE CLASS ACTION REFORM
}

\author{
DEBORAH R. HENSLER* AND THOMAS D. ROWE, JR.**
}

\section{INTRODUCTION}

We begin with the premise that private class actions for money damages can yield significant social benefits. Class actions for damages can provide compensation for modest but non-trivial losses suffered by widely dispersed but similarly positioned persons as a result of the negligence or illegal behavior of others, allowing recovery for losses that cannot practically be achieved through individual litigation. In this way, damage class actions can deter such injurious behavior and thereby supplement regulatory enforcement by administrative agencies that are under-funded, susceptible to capture by the subjects of their regulation, or politically constrained. Damage class actions also may provide efficient management and resolution of large numbers of similar claims when individual litigation is feasible, but its costs would be extraordinarily high. ${ }^{1}$

Despite these benefits, however, the financial incentives that fuel private class action litigation have the potential to undermine these goals. Private litigation that duplicates effective regulatory enforcement may impose additional costs without commensurate benefits. Non-meritorious class actions filed by lawyers who expect defendants to be willing to pay something simply to ensure that the class counsel will "go away," as well as class action settlements that bear little relation to the merits of the claims, dilute the deterrent effect of class action litigation. Settlements designed in ways that make it unlikely that the defendants will deliver all of the benefits they have pledged to pay class members

Copyright (c) 2001 by Deborah R. Hensler and Thomas D. Rowe, Jr.

This article is available at http://www.law.duke.edu/journals/64LCPHensler.

* Judge John W. Ford Professor of Dispute Resolution, Stanford Law School, and Senior Fellow, RAND Institute for Civil Justice.

** Elvin R. Latty Professor of Law, Duke University School of Law.

Thanks for discussion of the ideas considered in this paper, or comments on early drafts, go to Professor Janet Cooper Alexander, Mark Stein, students in Professor Rowe's Access to Civil Justice seminar, and participants in Duke and Stanford law faculty workshops. An earlier draft of this paper was presented at the Conference on Complex Litigation co-sponsored by Duke University and The Institute for Law and Economic Policy in Naples, Florida, on April 14-15, 2000. Errors are ours.

1. Asbestos worker injury lawsuits are an example of large-scale litigation usually pursued outside a class action framework. In the early 1980s, RAND analysts found that transaction costs in this litigation accounted for about $60 \%$ of the total amount defendants paid to resolve claims. See JAMES S. KAKALIK ET AL., RAND, VARIATION IN ASBESTOS LITIGATION COMPENSATION AND EXPENSES (1984); JAMES S. KAKALIK ET AL., RAND, COSTS OF ASBESTOS LITIGATION (1983). 
will not achieve their asserted compensation objectives. The efficiency gains flowing from global resolutions of claims may be outweighed by settlements that invite vast numbers of product users with weak or questionable claims to apply for benefits. During the 1990s, as damage class actions grew in number and scope, both scholarly and public policy discourse on this subject focused on such negative outcomes.

The theoretical bases for the concern that the goals of representative litigation may be thwarted have been well developed. To avoid litigation costs and small risks of large judgments, some defendants are willing to settle even very weak claims for their nuisance value. The incentive to settle nuisance claimsalways present in litigation-is particularly great in large-scale representative litigation, with its higher-than-average risks. Recognizing this, some plaintiffs' attorneys search out defendants who can be easily persuaded to settle such claims, often earning attorneys' fees that are disproportionate to the modest effort and expense required to achieve these settlements. Conversely, some defendants who face stronger claims may seek out plaintiffs' attorneys who are willing to settle such claims at less than their true value in exchange for fees that arguably are more generous than they deserve, given what they have obtained for their class clients. In both instances, the defendants buy res judicata at an inappropriate price: In the first instance, they pay too much (and the plaintiffs' attorneys pocket the premium); in the second, they pay too little (and class members suffer the loss). In both instances, because clients in representative litigation usually cannot effectively control their attorneys, unfaithful plaintiff attorney-agents are free to pursue their own interests. In addition, the deterrent signals of litigation are distorted because the costs of the harms that are imposed on the class are not properly reflected by settlement outcomes. ${ }^{2}$

The empirical evidence that supports the theoretical concerns is not as fully developed. No comprehensive assessment of the costs and benefits of damage class actions has been compiled, and no such assessment is in progress. ${ }^{3}$ Empiri-

2. See, e.g., John C. Coffee, Jr., Rescuing the Private Attorney General: Why the Model of the Lawyer as Bounty Hunter Is Not Working, 42 MD. L. REV. 215 (1983); John C. Coffee, Jr., Understanding the Plaintiff's Attorney: The Implications of Economic Theory for Private Enforcement of Law Through Class and Derivative Actions, 86 ColuM. L. REV. 669 (1986); Jonathan R. Macey \& Geoffrey P. Miller, The Plaintiff's Attorney's Role in Class Action and Derivative Litigation: Economic Analysis and Recommendations for Reform, 58 U. CHI. L. REV. 1 (1991); see generally John C. Coffee, Jr., The Regulation of Entrepreneurial Litigation: Balancing Fairness and Efficiency in the Large Class Action, $54 \mathrm{U}$. CHI. L. REV. 877 (1987).

A further problem is that even when more faithful agents are available to pursue plaitiffs' claims, current rules and practices favor those who are quickest to offer a settlement to defendants, rather than those who are most willing to invest the appropriate resources to develop the claims and obtain a fair outcome. However, such rules and practices are not necessary accoutrements to representative litigation and could be modified to facilitate the success of attorneys who are more faithful to class members' interests. See discussion infra Part III.

3. Because there is not a complete listing of all class actions filed or disposed nationwide-or even just all those in the federal courts-there is no sound basis for selecting a representative sample of class actions for research purposes. Because most class actions are settled rather than adjudicated, far less than all information relevant for assessing their costs and benefits is publicly available. Moreover, just what should be regarded as "costs" and "benefits" is contested. See DebORAH HensLer Et AL., 
cal investigation of a small number of cases suggests, however, that the merits of some class actions are questionable and that some class action settlements provide more benefits for class counsel and defendants than for class members. Moreover, concerns about filing and settlement practices gain credence because they are expressed by lawyers and interest-group advocates on both the plaintiffs' and defense sides of the litigation, persons who do not routinely agree with one another.

The controversy over whether it is possible to craft a damage class action regime that is, on balance, socially beneficial dates back (at least) to the 1966 revision of Federal Rule of Civil Procedure 23. As concern about class action abuses has grown, some critics have called for eliminating consumer and other class actions in which the losses claimed for individual class members are modest. $^{4}$ Other critics have urged the exclusion from class certification of those tort actions in which there is a credible opportunity for individual litigation. Some of these critics oppose the principle of using collective litigation to achieve regulatory enforcement or tort compensation objectives. ${ }^{5}$ Still other critics support the goals of collective litigation but believe that the financial incentives that fuel damage class actions are so strong that, in practice, these goals are subverted more often than not. ${ }^{6}$

To date, no political consensus has emerged about the appropriate use of damage class actions. A long effort by the Civil Rules Advisory Committee in the 1990s to reform Rule 23 largely foundered, mostly as a result of this lack of consensus. ${ }^{7}$ But calls for reform persist, and both Congress ${ }^{8}$ and the federal judiciary ${ }^{9}$ have taken up the matter yet again. The persistent chorus of criticismsupported by anecdotes about absurd claims and outrageous settlements-has the potential to erode societal support for damage class actions. This possibility should challenge supporters of procedures to remedy collective harms through private litigation to propose policies to calibrate better the aggregate benefits and costs of damage class actions.

RAND, Class Action Dilemmas: Pursuing Public Goals for Private Gain 401-02 (2000) (discussing obstacles to assessing empirically the costs and benefits of damage class actions).

4. See Working Papers of the Advisory Committee on Civil Rules vols. $2-4$ (1997) [hereinafter WORKING PAPERS]; Notes on Meetings, Report of the Advisory Committee on Civil Rules and the Working Group on Mass Torts to the Chief Justice of the United States and to the Judicial Conference of the United States, Minutes from Apr. 23-24, 1998 (Feb. 15, 1999); see also William T. Coleman, Statement on the Proposed Amendments to FED. R. CIV. P. 23 Before the Advisory Committee on Civil Rules (Nov. 22, 1996), reprinted in 4 WORKING PAPERS, supra, at 449, 457.

5. See generally WORKING PAPERS, supra note 4, vols. 2-4.

6. See id.

7. For a description of the Committee's reform effort, see HENSLER ET AL., supra note 3, at 25-37 (reviewing testimony and debate on the Civil Rules Advisory Committee's proposed amendments to Rule 23). As this article was being written, Rule 23 reform is once again before the Advisory Committee.

8. See, e.g., Consumer Rights in Federal Class Actions Act of 2000, S. 3123, 106th Cong. (2000).

9. See Judicial Conference Hones Proposal to Revamp Class Action Procedure Rule, 69 U.S.L.W. 2457 (2001); Lee H. Rosenthal, Renewed Examination of Federal Rule of Civil Procedure 23 in 2000, 69 U.S.L.W. 2163 (2000). 
To this end, in this article we explore alternative strategies for class action reform aimed at improving the cost-benefit ratio of a damage class action regime. Our analysis draws on RAND's recently completed study of contemporary damage class action practice ${ }^{10}$ and on the extensive theoretical literature on entrepreneurial litigation. Our goal is to identify mechanisms for enhancing the system's capacity to screen out non-meritorious suits, while preserving access for meritorious actions. While recognizing other concerns related to class actions (such as agency problems between class counsel and class members, and ethical issues), we do not address these problems except as they pertain to the question of screening. Similarly, we do not attempt to discuss the full range of proposals that have been put forward to address the various perceived problems relating to damage class actions, but instead focus on those proposals that are most relevant to the question of screening.

The first two strategies we consider would attempt to enhance the system's screening capacity directly, at the front end of the litigation process, by applying a cost-benefit test at the time of certification, or by requiring class members to decide whether to participate at the inception of litigation. Part II briefly describes these strategies. We conclude that it is unlikely that judges could apply a cost-benefit test fairly and consistently, and that an opt-in requirement might screen out as many meritorious suits as non-meritorious actions (if not more).

The next two strategies would attempt to enhance the system's screening capacity indirectly, at the back end rather than the front end. The first and relatively non-controversial back-end strategy relies on judges to use more vigorously their authority to scrutinize class action settlements and fee award requests. By better calibrating the benefits to class members and financial rewards to class counsel, more rigorous judicial management would drive out "bad" class actions while maintaining access for meritorious lawsuits. The theoretical literature on entrepreneurial litigation and RAND's case study investigations provide the grounding for this strategy, which we discuss in Part IIIA.

While we believe that increased judicial scrutiny could substantially improve the system's screening capacity, relying solely on judicial discretion for regulatory purposes has some obvious weaknesses-particularly in our federal system, in which parties who cannot satisfy one judge may simply depart that jurisdiction for another whose judges are more congenial. Hence, in Part IIIB we consider a different and more controversial approach to re-calibrating incentives to file and settle non-meritorious suits: adopting loser-pays attorney fee-shifting for certified damage class actions, with liability on the plaintiffs' side borne by class counsel. Although critics of class actions have proposed other manipulations of financial incentives, such as auctions, to improve the cost-benefit ratio of damage class actions, those who support the use of representative litigation in at least some circumstances have generally rejected fee-shifting out of hand. Our analysis suggests that such a version of loser-pays might have some positive

10. See HENSLER ET AL., supra note 3. 
effects on the damage class-action regime by increasing the costs of bringing non-meritorious suits, while at the same time somewhat increasing the benefits of pursuing meritorious cases. The many practical problems associated with integrating this approach into American class action practice, however, raise questions about its practicability, and it is unclear whether the posited improvements in the cost-benefit ratio would be large enough to merit seeking solutions to these knotty problems. Hence we conclude by urging further attention to judicial regulation, while inviting more serious scholarly consideration of fee-shifting strategies.

II

\section{FRONT-END STRATEGIES}

If too many non-meritorious damage class actions are coming through the courthouse doors, then it might seem attractive to adopt strategies that would raise the bar for certification or participation. Two such strategies have attracted attention in recent years: (1) imposing a cost-benefit test for certification and (2) requiring those who want to be part of the class to come forward at the inception of the litigation (that is, "opt in"), rather than relying on their passive consent to legitimize the suit. After carefully considering both strategies, we think it is questionable whether they would consistently and fairly screen out non-meritorious lawsuits, while ensuring access for meritorious cases. Imposing a cost-benefit test for certification would encourage judges to make meritsbased decisions without adequate grounds for these decisions. Requiring class members to opt in would deny access to those who have suffered losses too small to permit them to secure legal representation, without regard to the substantive merits of their claims against those whose actions led to the losses.

\section{A. Imposing a Cost-Benefit Test for Certification}

If, as some critics claim, judges too often certify damage class actions when class members have little to gain-while defendants and the court system face large costs - it would be logical to stiffen the criteria for certification. The Federal Civil Rules Advisory Committee proposed to do just that in 1996, when it published proposed amendments to Rule 23(b)(3) that included a new factor (F) for judges to consider when deciding on certification: "whether the probable relief to individual class members justifies the costs and burdens of class litigation." be revived any time soon. ${ }^{12}$ By reviewing the issues raised by the proposal, however, we can better understand the problems that would be encountered by

11. Proposed Amendments to the Federal Rules of Civil Procedure, 167 F.R.D. 559, 559 (1996).

12. See Hensler ET AL., supra note 3, at 32-37 (recounting history of Advisory Committee consideration and abandonment of proposed factor $(\mathrm{F})$ ). 
efforts to reform the damage class action regime by incorporating cost-benefit or merits-based assessments into the certification decision. ${ }^{13}$

The Committee's proposal—soon dubbed the "it just ain't worth it" ruleincited a storm of opposition from legal scholars and consumer advocates, who argued that it would gravely threaten the use of class actions for regulatory enforcement. ${ }^{14}$ In addition, how the provision would be implemented remained unclear. What evidence would a judge have before her at the time of certification-supposed, under the rule, to take place early in the litigation processto ascertain what class members would likely receive, and what the likely costs would be? Ultimately the many difficulties with the proposal led the Advisory Committee to abandon consideration of factor $(\mathrm{F}) .^{15}$

The debate over the consequences of factor $(F)$ for regulatory enforcement quickly overshadowed concerns about the practical application of the new provision, but the concerns were valid. RAND's recent case studies of damage class actions found that arguments about what is at issue in these lawsuits-the legal merits of the claims and how to assess damages at both the aggregate and individual levels-may persist until late in the litigation. ${ }^{16}$ In some instances, there is extensive discovery on these points. Determining the "probable relief" to class members at the inception of such litigation would pose a considerable challenge. Indeed, if the terms of a settlement call for a pro rata division of the aggregate recovery among all eligible claimants, and the number of claimants who will come forward is unknown-as is often the case-the size of individual shares may not be known until after a class action is settled. ${ }^{17}$

13. Cost-benefit and merits-based tests, although they might overlap (and could be confused with each other), are conceptually separable. A cost-benefit assessment can ask whether, assuming that the claims of the plaintiff class have merit, the likely relief to class members would be worth the costs and burdens of litigation in class form. A merits-based factor, far from assuming anything, would preliminarily evaluate the merits of the plaintiff class's claims and give weight to the presence or absence of likely merit in deciding for or against class certification. In practice, as we explain in the text, the two tests might conflate.

Under existing rules judges can, of course, dismiss class actions for failure to state a claim or by summary judgment. In its 1996 study of class actions in four federal district courts, the Federal Judicial Center found that judges ruled on summary judgment motions in about five to ten percent of cases with class allegations; in the majority of these cases, the rulings were made after certification. See THOMAS Willging et al., Federal Judicial Ctr., EMPIRICAl Study of Class ACtions in Four FEDERAl District COURTS: FInAl RePORT TO THE ADVISORY COMMITTEE ON CIVIL RULES 171 tbls. 23-24 (1996). Judges ruled on motions to dismiss in more than half of the cases and dismissed 15 to $34 \%$ of these cases, with different percentages across the four courts. Id. at $171 \mathrm{tbl} .24$.

14. Testimony before the Advisory Committee indicates that at least some supporters of the proposed amendment intended that effect and that contending views on the objectives of damage class actions underlay the controversy over the adoption of factor (F). See HENSLER ET AL., supra note 3, at 32-35 (reviewing testimony and debate on the Civil Rules Advisory Committee's proposed amendments to Rule 23).

15. See Minutes, Civil Rules Advisory Committee (Oct. 6-7, 1997) (visited Mar. 7, 2001) $<$ http://www.uscourts.gov/rules/Minutes/cv10-97.htm> (discussing Rule 23, Factor (F)).

16. See HENSLER ET AL., supra note 3, at 416-24.

17. Ironically, judges would be most likely to have the information necessary for determining the benefit side of the cost-benefit equation when they were certifying settlement class actions-that is, when class counsel and defendant join in requesting certification after they have negotiated a settlement. But the Advisory Committee's proposed amendment to provide for settlement class actions 
The cost side of the cost-benefit test is even less susceptible to judicial determination. Whereas courts often (although not always) know what benefits claimants are likely to collect once a class action has been settled or adjudicated, they virtually never know the costs of class litigation. Because judges award class counsel fees, they determine a portion of these costs themselves. But fees are most frequently awarded on a percentage-of-fund ("POF") basis; therefore, a judge who does not know the size of a potential aggregate recovery at the time of certification will also not know the likely amount of class counsel fees. Moreover, the judge will virtually never know how much defendants pay their lawyers in fees and expenses. Because this information is not a matter of public record, judges have no evidence from prior cases on which to base estimates of the total costs of class litigation. Relying on defendants' estimates of projected costs at the start of the litigation when certification is contested would raise serious fairness questions.

If judges faced the dilemma of having to decide whether the probable relief to class members outweighed the costs without adequate information for such an assessment, it is uncertain what they would do. We may speculate that some would base their decisions on their general views regarding the costs and benefits of different types of class actions. Others might rely on their assessment of the merits of the case before them. During its deliberations on amendments to Rule 23(b)(3), the Advisory Committee considered including a provision for judges to take a preliminary "peek at the merits" among the certification factors. $^{18}$ At first, some representatives of corporate defendants supported this idea; but the Committee later put it aside, in part in reaction to concerns that emerged as corporate representatives considered the potential consequences of asking judges to rule, even in provisional fashion, on the merits of a case before the facts or legal issues had been reasonably well developed. ${ }^{19}$

RAND's case study analyses suggest that taking preliminary assessments of the merits of class actions into account in certification rulings would likely yield inconsistent outcomes. After reviewing information about the claims underlying ten recent damage class actions, RAND's analysts wrote: "We felt like members of the audience at a production of the Japanese drama 'Rashomon.' Viewed from one perspective, the claims appear meritorious and the behavior of the defendants blameworthy, but viewed from another, the claims appear trivial or even trumped up, and the defendant's behavior seems proper." ${ }^{20}$

Efforts to incorporate cost-benefit or merit-based tests among the certification factors are appealing because they hold out the possibility of diverting

evoked at least as much controversy-for totally different reasons-as the "it just ain't worth it" rule. See HENSLER ET AL., supra note 3, at 31-37.

18. Such a rule amendment would have overruled the aspect of Eisen v. Carlisle \& Jacquelin, 417 U.S. 156 (1974), in which the Supreme Court said, "We find nothing in either the language or history of Rule 23 that gives a court any authority to conduct a preliminary inquiry into the merits of a suit in order to determine whether it may be maintained as a class action." Id. at 177.

19. See HENSLER ET AL., supra note 3, at 44 n.103.

20. Id. at 417 . 
"bad" cases from the legal system before significant costs have been incurred. Eliminating such cases early would also diminish the oft-mentioned in terrorem effect of class actions, which defendants explain as the threat posed by even a modest potential for huge class-wide damages that class counsel can threaten once a case has been certified. ${ }^{21}$ The empirical evidence suggests, however, that the search for a cost-benefit or merit-based standard that can be incorporated into the certification process (in addition to the present criteria relating to the form of the litigation ${ }^{22}$ and functional concerns, ${ }^{23}$ and the possibilities of dismissal and summary judgment) may be quixotic. It is difficult to design a fair and adequate procedure for a preliminary determination of the merits, and it is similarly difficult to imagine a cost-benefit test that does not at least implicitly, if not explicitly, incorporate a preliminary merits determination.

\section{B. Requiring Class Members to Opt In}

For corporate defendants, the most significant provision of the 1966 revisions to Rule 23 was the substitution of an opt-out provision for the de facto opt-in requirement of the "spurious" class action that before 1966 most resembled Rule 23(b)(3) actions for money damages. ${ }^{24}$ As a result, the scope of money damage lawsuits - and hence the financial exposure of the corporations against whom they usually were brought—multiplied many times over. Previously, the class would have included only those similarly situated persons and entities that were aware of the action and wished to join it. Now, all those who met the class definition and did not come forward-potentially hundreds of thousands or even millions of people-were included in the litigation, and if it succeeded, all might be eligible to receive damage awards. ${ }^{25}$

21. See, e.g., Developments in the Law-The Paths of Civil Litigation: IV. Class Action Reform: An Assessment of Recent Judicial Decisions and Legislative Initiatives, 113 HARV. L. REV. 1752, 1811 (2000) [hereinafter Developments] ("For defendants, the potential liability that attaches to damages class actions is so great that often the most sensible solution is to settle as early and as cheaply as possible." (footnotes omitted)); Jack B. Weinstein, Some Reflections on United States Group Actions, 45 AM. J. COMP. L. 833, 834 (1997) ("Among [the class action's] disadvantages are the enormous power and threat of large aggregations that may induce defendants to settle claims that have little merit ....").

22. That is, the Rule 23(a) criteria of numerosity, commonality, typicality, and representativeness.

23. That is, the Rule 23(b)(3) factors of manageability and superiority.

24. The 1938 version of Rule 23 provided for three types of class actions, dubbed "true," "hybrid," and "spurious." "Spurious" class actions bound only the class representatives and those absentee class members who explicitly chose to be bound. See Developments in the Law: Multiparty Litigation in the Federal Courts, 71 HARV. L. REV. 874, 930 (1958). The 1966 amendments substituted a new set of categories of class actions, only one of which (the (b)(3) suit) requires notifying absent parties about the pendency of the action and permitting them to exclude themselves from the litigation. See Benjamin Kaplan, Continuing Work of the Civil Committee: 1966 Amendments of the Federal Rules of Civil Procedure (1), 81 HARV. L. REV. 356, 386 (1967).

25. Corporate exposure to damage class actions was further increased by the passage during the 1970s of consumer and other legislation that provided new substantive grounds for collective litigation and by court rulings that interpreted the new rule expansively. Business media during this period vividly reflected corporate concerns about the import of the new rule. See HENSLER ET AL., supra note 3, at 15-17 (discussing early judicial decisions under revised Rule 23, congressional passage of consumer legislation, and business community's reaction to the 1966 rule revisions). 
Over the past several years, some critics of damage class action practice have proposed a return to an opt-in requirement for Rule 23(b)(3) suits. ${ }^{26}$ They argue that requiring those who want to be bound by a class action outcome to opt in would enhance the system's ability to screen out trivial and nonmeritorious lawsuits. Large numbers of class members would come forward, these critics assert, when there was a widely shared perception that the alleged wrongdoing was significant and that the potential remedies were worth pursuing. ${ }^{27}$ Hence the value of damage class actions in these circumstances would be preserved. But when the wrongdoing was insignificant or the remedies trivial, few people would come forward. This response would reduce the in terrorem effect of filing a class action in such circumstances, encouraging defendants to contest non-meritorious suits. In addition, judges might decline to certify a class if only a small fraction of eligible class members opted in. Faced with a higher risk of not covering their costs to pursue a class action, plaintiffs' attorneys would be less likely to file non-meritorious suits and suits in which the likely remedies were trivial.

We agree that class size very likely would be smaller if class members were required to opt in and that the rate of opting in would be especially low when individual losses were small. As a result, we would expect the rate of filing class actions for small losses to consumers to decline under an opt-in regime. But we suspect that the lawsuits that would effectively be denied access to the legal system would include substantively meritorious as well as substantively nonmeritorious claims. Conditioning the prosecution of a class action on class members having suffered substantial individual losses would thus subvert what many believe to be one of the key purposes of collective action, ${ }^{28}$ namely facilitating litigation precisely when many persons have suffered, as a result of an-

26. In a speech to the National Press Club in Washington, D.C. on May 20, 1998, reviewing the controversy over damage class actions and the rule reform effort, the then-Chair of the Civil Rules Advisory Committee, Judge Paul Niemeyer of the Fourth Circuit, observed:

The inertia of not responding [to notices calling for class members to opt out] has been iden-

tified as the cohesive force behind the viability of plaintiff class actions. [Requiring indi-

viduals to opt in] is ... the change to the rule that could be made to eliminate most of the

class actions or radically reduce their size.

Paul Niemeyer, Speech to the National Press Club (May 20, 1998) (transcript on file with the authors).

27. Whether and when to substitute an opt-in provision for the opt-out approach of Rule 23(b)(3), and what the consequences of such a change would be, surfaced in testimony before the Civil Rules Advisory Committee. See e.g., Testimony of Alfred Cortese, San Francisco, Ca. 11 (Jan. 17, 1997), reprinted in 3 WORKING PAPERS, supra note 4, at 280; Statement of Alfred Cortese, reprinted in 4 WORKING PAPERS, supra note 4, at 387.

28. Albeit a contestable purpose: During the debate over proposed revisions to Rule 23 in the 1990s, some members of the 1966 Civil Rules Advisory Committee argued that it was never the intent of the drafters to facilitate class actions for regulatory enforcement purposes. See, e.g., Coleman, supra note 4, at 455-57; Intellectual Property and Class Action Lawsuits, 1998: Hearings Before Subcomm. on the Courts and Intellectual Property of the House Comm. on the Judiciary, 105th Cong. 57-80 (1998) (testimony of John Frank). But cf., e.g., Phillips Petroleum Co. v. Shutts, 472 U.S. 797, 809 (1985) (Rehnquist, J.) ("Class actions ... may permit the plaintiffs to pool claims which would be uneconomical to litigate individually. For example, this lawsuit involves claims averaging about $\$ 100$ per plaintiff; most of the plaintiffs would have no realistic day in court if a class action were not available."). 
other's wrongdoing, losses that are too modest to allow them to obtain individual counsel.

Returning to an opt-in requirement for damage class actions would leave in place a vehicle for collective litigation, but the vehicle would be substantially under-powered in comparison to the current model. ${ }^{29}$ The deterrence capacity of the legal system would be limited to those instances in which defendants visited substantial harm upon individuals, leaving actions that cause small harms to large numbers of persons-and may secure large benefits to the wrongdoersunrestricted by private law. Whatever their opinion on the proper role of private class actions in regulatory enforcement, it seems that all would have to agree that such a change in Rule 23 , rather than being merely "procedural," would effect a significant change in the substantive law, and hence is a matter for Congress to decide. ${ }^{30}$

Moreover, there is some reason to question the intuition that failing to respond to an invitation to participate in a process-for example, to opt in-necessarily connotes a preference not to participate. Social scientists have investigated the difference in participation rates when subjects are alternately asked to consent actively or passively to research. For example, parents may be asked either to sign forms permitting their children to take certain tests and return them to the children's teacher ("active consent") or to fill out a form saying they do not want to participate. In the latter instance, all those who do not return forms are deemed to have given "passive consent." Participation rates are much higher under a passive-consent regime because, typically, relatively small numbers come forward to object. The difference between participation rates under the two regimes would be a matter of concern if it indicated that the active-consent regime provided a better mechanism for parents to object to their children's participation, by comparison with the passive-consent regime. But, by interviewing parents, the researchers have found that most of those who do not sign up in an active-consent regime-and are therefore deemed objectorsin fact do not object to the proceedings and would have been happy to participate. They either never received the consent form, mislaid it, or were simply too busy to fill it out. Those who are less well educated (and in this research,

29. Limiting class certification to situations in which persons who have suffered significant losses individually also would inevitably lead to questioning the appropriateness of certification for these situations. Mass tort class actions illustrate this conundrum. Unlike most consumer class actions, most mass tort class actions comprise individual claims worth at least some thousands of dollars, and often much larger sums. Hence we might expect that potential class members would pay attention to notices and take actions necessary to obtain compensation under a class settlement. But absent a class action, many of these people would arguably be able to obtain legal representation and seek compensation individually. As a result, critics of mass tort class actions argue that it is inappropriate to certify such cases.

30. Diluting the power of Rule 23(b)(3) damage class actions would also call into question the viability of consumer protection legislation passed over the past several decades that assumes that consumers will have recourse to Rule 23(b)(3) class actions to secure the remedies promised under law. See Arthur Miller, Of Frankenstein Monsters and Shining Knights: Myth, Reality and the "Class Action Problem," 92 HARV. L. REV. 664 (1979) (discussing consumer-protection litigation passed after the adoption of Rule 23(b)(3)); HENSLER ET AL., supra note 3, at 16-18. 
minority-group members) are less likely than others to respond in the activeconsent regime. ${ }^{31}$

By extrapolation, this research suggests that an opt-in class action regime might screen out many who would, in fact, wish to participate in a lawsuit brought on their behalf but did not take the steps necessary to opt in. The research also suggests that an opt-in rule might have uneven effects on citizens of different socio-economic, racial, and ethnic groups.

In sum, an opt-in regime would likely screen out many potential class action lawsuits, but it seems unlikely that the operation of such a screen would improve the social cost-benefit ratio of damage class actions. Claims that were strong on the merits might fail simply because the losses to individuals were too small to attract their attention, and the effects of an opt-in requirement might be felt more by poorer and minority citizens.

III

\section{THE INDIRECT APPROACH: RE-CALIBRATING THE INCENTIVES}

Critics who believe that current class action rules leave the door to the courthouse open too wide see in the certification process the means of shutting that door, or at least narrowing the means of ingress. ${ }^{32}$ But we are not persuaded that the approaches that have been suggested for limiting certification would effectively screen out non-meritorious cases while also ensuring access for meritorious claims. Hence, we consider two back-end strategies for recalibrating the incentives damage class actions offer attorneys and parties: more rigorous judicial scrutiny of settlement terms and class counsel fee requests, and adopting a loser-pays fee shifting rule with liability on the plaintiffs' side on the attorneys. The first strategy is relatively uncontroversial because it calls for implementation of extant rules; but it requires a significant shift in the current judicial culture-which celebrates settlement over judicial decisionmaking-as well as substantial court resources. In addition, its effectiveness depends on consistent application of rigorous standards, which may be defeated by the opportunities for forum-shopping provided by our federal system. The second strategy is highly controversial, and has received little attention in the scholarly literature on damage class actions. In theory, it might help to screen out "bad" suits, while preserving - perhaps even encouraging-meritorious actions. Its effects might be quite modest, however, and not worth the practical difficulties that would have to be overcome in incorporating such a rule into American litigation practice.

31. See, e.g., Phyllis Ellickson, Getting and Keeping Schools and Kids for Evaluation Studies, Monograph Series CSAP Special Issue, J. COMMUN. PSYCH. 102 (1994).

32. See generally Rosenthal, supra note 9, at 2165 (characterizing the present Advisory Committee consideration of possible Rule 23 changes as shifting from certification standards, which had been the subject of many proposals in an earlier part of the process, to a "process of class action practice" including review of proposed settlements); WORKING PAPERS, supra note 4, vols. 2-4. 


\section{A. More Rigorous Judicial Regulation of Class Action Settlements and Fees}

Judges have powerful tools under current law for adjusting the incentives for entrepreneurial lawyers to file and prosecute damage class actions, for defendants to contest them, and for both class counsel and defendants to negotiate settlements that serve the interests of class members. By granting summary judgment when appropriate, denying approval to questionable settlements, and carefully matching fee awards to the actual benefits conferred on class members, judges can send powerful messages to class counsel that prosecuting nonmeritorious suits will not be remunerative, while vigorous advocacy on behalf of properly constituted classes will be rewarded. Then, over the long run, class action attorneys would have fewer incentives to come knocking on the courthouse door requesting certification for non-meritorious suits, but the door would remain open for meritorious claims that satisfy the procedural requirements of class representation.

In their case studies of ten recent damage class actions, RAND analysts found wide variation in what was delivered to class members as a result of litigation, and in what class counsel received in return. For example, in one case a judge approved a settlement valued at $\$ 67$ million, half to be paid in cash and half in coupons redeemable for the defendant's products, with class counsel being awarded $\$ 8.5$ million. ${ }^{33}$ To claim these benefits, class members had to request and complete a fairly complex form. The judge did not require information on payments to class members to be reported to the court, and class counsel and the defendant agreed to keep that information confidential. Based on review of financial reports and other public documents, RAND estimated that about $\$ 9.2$ million-just a bit more than the amount paid in attorney fees-was ultimately paid to class members by the defendant. ${ }^{34}$ Information on the number of coupons redeemed was not available.

In another case that RAND studied, class counsel and the defendant initially proposed a monetary settlement valued at $\$ 6.7$ million. ${ }^{35}$ Under the settlement agreement, class counsel were to receive $\$ 5.398$ million of the common fund, and any funds remaining after the end of the claim period would revert to the defendant. The basis for the fee request-which amounted to about eighty percent of the common fund-was the combined value of the monetary settlement plus the asserted "injunction value" of the class action, estimated at $\$ 11.7$ million by class counsel's expert. But the defendant's practice changes that were the basis for claiming that the suit secured injunctive relief appeared to have occurred some time before the filing of this class action, probably in response to previous litigation. Based on previous experience settling similar cases, the attorneys negotiating this settlement apparently believed that the

33. See HENSLER ET AL., supra note 3, at 145-68 (discussing Roberts v. Bausch \& Lomb, Inc., No. CV-94-C-1144-W (N.D. Ala. Nov. 26, 1996)).

34. See id.

35. See id. at 191-206 (discussing Graham v. Security Pacific Housing Services, No. 2:96-CV-132 (S.D. Miss. June 26, 1997)). 
judge would approve it. But after the judge granted permission for Trial Lawyers for Public Justice to intervene, the public interest attorneys raised questions about virtually every aspect of the proposed settlement, and it was renegotiated. The common fund was increased to $\$ 10.5$ million and the fee request was reduced to $\$ 1.92$ million, to be paid out of the fund. An automatic disbursement process was devised to assure that all eligible class members would secure payment, and virtually all of the funds were ultimately paid out to class members.

RAND interpreted the case-study findings as demonstrating that when judges scrutinized proposed settlements and fee requests more closely and refused to approve questionable deals and requests, class members received more of what defendants were willing to pay to settle the cases. The analysts concluded that

the balance of benefits and costs was more salutary when judges:

- required clear and detailed notices

- closely scrutinized the details of settlements including distribution strategies

- invited the participation of legitimate objectors and intervenors

- took responsibility for determining attorney fees, rather than simply rubberstamping previously negotiated agreements

- determined fees in relation to the actual benefits created by the lawsuit [and]

- required ongoing reporting of the actual distribution of settlement benefits. ${ }^{36}$

Based on its research, the RAND team also concluded that judges need more help in determining whether proposed settlements are "fair, adequate, and reasonable ${ }^{37}$ and in deciding what fees are appropriate. ${ }^{38}$ To assist in deciding whether to approve proposed settlements, the analysts recommended that judges require information about total estimated damages suffered and cast

36. Deborah Hensler ET Al., RAND, Class ACtion Dilemmas: Pursuing Public GoAls FOR PRIVATE GAIN- EXECUTIVE SUMMARY 24-25 (1999).

The RAND researchers' findings in actual cases thus cast doubt on the argument of Professor Coffee that "reliance on trial court scrutiny of the settlement" is "sure to fail." John C. Coffee, Jr., Class Action Accountability: Reconciling Exit, Voice, and Loyalty in Representative Litigation, 100 COLUM. L. REV. 370, 438 (2000). Experience with such scrutiny, facilitated by concrete measures such as fostering legitimate objectors' participation and tying fees to actual benefits delivered, which can be promoted by appellate decision or positive law, indicates that trial judges can indeed improve questionable settlements. True, "[s]ound policy must rest on a sound theory," Coffee, supra, at 438 n.169, but it must also rest on the changes in present approaches that empirical study suggests can respond to existing problems.

37. Proponents of settlement have the burden of satisfying the judge that the settlement is "fair, adequate, and reasonable." Cotton v. Hinton, 559 F.2d 1326, 1330 (5th Cir. 1977); Grunin v. International House of Pancakes, 513 F.2d 114, 120 (8th Cir. 1975).

38. In an article published in 1995, Judge William Schwarzer proposed amending Rule 23(e), calling for judges to make findings with respect to 11 factors, including class definition, treatment of class members with possibly diverse interests, opt-out rights, attorney fees, benefits to class members, and costs to defendants. See William W Schwarzer, Settlement of Mass Tort Class Actions: Order Out of Chaos, 80 CORNELl L. REV. 837, 843-44 (1995). The Advisory Committee on Civil Rules is currently considering adding to Rule 23 a provision that would require judges to make similar findings. See Rosenthal, supra note 9, at 2165. 
a skeptical eye on aggregate remedies that fall far short of reasonably estimated damages, adjusted for the apparent strength of the legal claims. ${ }^{39}$ They also recommended that judges require settling parties to detail plans for disbursing benefits to eligible claimants and suggested that preference be given to automatic disbursement schemes, such as crediting accounts of eligible class members. The analysts urged judges to scrutinize closely proposals to deliver benefits in the form of coupons and to require that parties making such proposals disclose expectations regarding coupon redemption rates. ${ }^{40}$ After approval of a settlement, RAND recommended that judges maintain oversight over settlement implementation and that they require detailed and timely reporting of disbursements (including, for example, coupon redemption rates) and costs. ${ }^{41}$

RAND's strongest recommendations pertained to fee awards: "The single most important action that judges can take to support the public goals of class action litigation is to reward class action attorneys only for lawsuits that actually accomplish something of value to class members and society." ${ }^{\prime 2}$ To this end, the analysts recommended that judges award fees based on the actual amounts paid out by defendants to class members, notwithstanding contrary case law. ${ }^{43}$ To accomplish this objective in litigation when settlements are paid over a long pe-

39. The Manual for Complex Litigation advises judges to compare the proposed settlement amount with the present value of the damages that plaintiffs would likely recover if successful, appropriately discounted for the risk of losing, and suggests that expert testimony may be helpful in this analysis. Federal Judicial CTR., MANUAL FOR COMPLEX Litigation (ThiRd) $§ 30.42$ (1995). But the Manual also cautions again requiring too much information, lest the costs of investigation outweigh the (perceived) benefits of settlement. See id.

40. HENSLER ET AL., supra note 36, at 32.

41. See id. at 32-33.

42. Id. at 33 .

43. See Boeing Co. v. Van Gemert, 442 U.S. 472 (1980); Hensler ET AL., supra note 3, at 81-83 (describing how the Boeing doctrine can contribute to collusion between class counsel and defendants).

In a recent case, Justice O'Connor called for examination of an issue not addressed in Boeing. This was "whether there must at least be some rational connection between the fee award and the amount of the actual distribution to the class." International Precious Metals Corp. v. Waters, 120 S. Ct. 2237, 2237 (2000) (O'Connor, J., respecting the denial of the petition for a writ of certiorari). Waters involved a fee award of $\$ 13,333,333$ out of a reversionary settlement fund of $\$ 40$ million, but the actual distribution to class members turned out to be only $\$ 6,485,362.15$. See Waters, $120 \mathrm{~S}$. Ct. at 2237. Although she concurred in the denial of certiorari because the defendants had agreed in the settlement not to contest the reasonableness of the fee award, Justice O'Connor observed:

Arrangements such as that at issue here decouple class counsel's financial incentives from those of the class, increasing the risk that the actual distribution will be misallocated between attorney's fees and the plaintiffs' recovery. They potentially undermine the underlying purposes of class actions by providing defendants with a powerful means to enticing class counsel to settle lawsuits in a manner detrimental to the class. And they could encourage the filing of needless lawsuits where, because the value of each class member's individual claim is small compared to the transaction costs in obtaining recovery, the actual distribution to the class will inevitably be minimal. ... I believe this issue warrants the Court's attention.

Waters, 120 S. Ct. at 2237-38.

Attorney fees based on a percentage of the amount of damages actually paid, plus prejudgment interest, are required under the Private Securities Litigation Reform Act of 1995, Pub. L. No. 104-67, 109 Stat. 737 (1995). 
riod of time, RAND recommended that judges make phased awards. ${ }^{44}$ If judges approve coupon settlements, the analysts suggested that they base fee awards on the monetary value of coupons redeemed, not offered..$^{45}$ They urged judges not to award fees for "illusory" relief, which they defined as changes in practice made in response to independent public enforcement actions or separate private litigation. ${ }^{46}$ They also suggested that judges consider awarding proportionally less for cy pres remedies when disbursement plans might have been devised to deliver the class benefits to class members themselves. ${ }^{47}$

Recognizing that some would argue that judges do not have the expertise or resources to conduct such detailed assessments of proposed settlements and fee award requests, RAND argued that judges could obtain considerable assistance from court-appointed neutral experts, objectors, and intervenors, as well as class members themselves. ${ }^{48}$ The analysts noted that each of these strategies has pitfalls but that judges who were committed to regulating damage class actions could avoid them. ${ }^{49}$ In the analysts' view, the biggest obstacle to judges taking greater responsibility for the quality of settlements and the appropriateness of fee awards is not lack of expertise or resources, but rather a judicial culture that places too high a premium on settlement. ${ }^{50}$

RAND's recommendations and similar proposals put forward by others hold practical promise within the present system to give class counsel incentives to resist the temptation to settle a class action on terms favorable to themselves but not good enough for the class. If consistently followed, these suggestions would have ex ante screening effects when potential class counsel consider whether to file an action in class form. Lawyers would have to consider more carefully whether they could get a settlement good enough for class members to pass muster with a judge, and whether they could get a fee large enough to make their investment in the case financially attractive. The new regime would significantly reduce the attraction of filing non-meritorious suits that could not satisfy more rigorous judicial standards for settlement approval and fee awards.

44. See Hensler ET AL., supra note 36, at 34. Judges have made such awards. See, e.g., Bowling v. Pfizer, Inc., 102 F.3d 777 (6th Cir. 1996), cert. denied sub nom. Ridgeway v. Pfizer, Inc., 522 U.S. 906 (1997) (upholding trial court fee award of $10 \%$ of the amount paid into the common fund to date, plus up to $10 \%$ of annual payments to be paid into a settlement fund over a period of 10 years); Duhaime v. John Hancock Mut. Life Ins. Co., 989 F. Supp. 375 (D. Mass. 1997) (court provisionally awarded fees as requested, ordered partial payment immediately, and reserved balance for payment in full or to be adjusted in light of the actual funds disbursed).

45. See Hensler ET AL., supra note 36, at 34. The National Association of Consumer Advocates has proposed that class counsel submit to the court detailed information about redemption rates and coupon transfers during the entire life of the coupon. See National Association of Consumer Advocates, Standards and Guidelines for Litigating and Settling Consumer Class Actions, 176 F.R.D. 375, 384 (1997).

46. See HENSLER ET AL., supra note 36, at 34.

47. See id.

48. See id.

49. See Hensler ET AL., supra note 3, at 493-97.

50. See id. at 497-98. 
But these measures, however meritorious, call for much back-end judicial scrutiny in individual cases and might be subject to considerable inconsistency in application, which would reduce their screening effect. Inconsistency in application has particularly powerful diluting effects in our highly permeable federal system, in which parties whose proposals do not satisfy one judge's strict standards may well be able to take those proposals to another jurisdiction where a different judge may look more kindly upon them. Hence, we turn in the next part to a fourth screening strategy, which is simpler but more controversial: loser-pays fee shifting with plaintiffs'-side lawyer liability.

B. A More Controversial Alternative: Loser-Pays Fee Shifting, with Liability on the Plaintiffs' Side Borne by Class Counsel

Many efforts to respond to perceived problems in class actions have focused on financial incentives affecting parties and counsel. ${ }^{51}$ One that has received only limited attention in recent discussions, and usually from foes of the class action ${ }^{52}$ is some form of loser-pays attorney fee shifting. As is widely known, most civil justice systems outside the United States impose some sort of fee shifting in ordinary litigation. Neither of us has been a general supporter of the loser-pays rule in such litigation, ${ }^{53}$ but we do not think it inappropriate in all forms and for all contexts. ${ }^{54}$ If adopting some form of fee shifting in damage class actions might encourage vigorous prosecution of meritorious class claims and discourage non-meritorious claims and meritless settlements, without imposing offsetting economic or social costs, we think it deserves a serious look. To our knowledge, this possibility has never received attention in any depth in the American literature on class actions, usually because it is regarded as incompatible with viable class litigation. ${ }^{55}$ However, the advent of a class action regime-and apparently vigorous practice-in Australia, a country that adheres to the "English rule" of costs following the event, challenges this assumption. ${ }^{56}$

Our discussion below is intended to stimulate thinking about the merits and demerits of instituting a particular form of fee shifting: two-way loser-pays fee

51. See, e.g., Developments, supra note 21, at 1827-51 (surveying proposals concerning calculation of plaintiffs' attorneys' fees for optimal investment of resources in class litigation, competitive bidding for lead class counsel role, and auctioning claims of class members).

52. See, e.g., Thomas D. Rowe, Jr., Indemnity or Compensation? The Contract with America, Loser-Pays Attorney Fee Shifting, and a One-Way Alternative, 37 WASHBURN L.J. 317, 322-23 (1998) (discussing fee-shifting provisions in early versions of Private Securities Litigation Reform Act of 1995).

53. See, e.g., Deborah R. Hensler, Taking Aim at the American Legal System: The Council on Competitiveness's Agenda for Legal Reform, 75 JUDICATURE 244 (1992); Rowe, supra note 52.

54. See, e.g., Attorney Accountability: Hearings Before the Subcomm. on Courts and Intellectual Property of the House Comm. on the Judiciary, 104th Cong. 44 (1995) (statement of Prof. Thomas D. Rowe, Jr.) ("[L]oser-pays fee liability may be easier to defend in some contexts where both sides will usually be well financed, such as commercial contract litigation."); Rowe, supra note 52, at 328 n.42 (distinguishing between broad loser-pays provisions and "more targeted approaches such as possible loser-pays fee shifting in connection with discovery disputes").

55. See, e.g., Weinstein, supra note 21, at 837 ("No United States plaintiffs' lawyer would take a case if he or she, or the nominal client, might be responsible for the defendant's legal fees.").

56. See S. Stuart Clark \& Christine Harris, Multi-Plaintiff Litigation in Australia: A Comparative Perspective, 11 DUKE J. COMP. \& INT'L L. (forthcoming 2001). 
shifting with liability on the plaintiffs' side borne by the lawyer. Fee-shifting would prevail only in specified circumstances after a class action has been certified and adjudicated to a conclusion. As will become clear, but may deserve stress at the outset, the basis for considering such a rule-the goal of properly calibrating the incentives to bring damage class actions-means that fee shifting would not be imposed as a sanction, but rather as a sheer costs-follow-the-event rule. Hence, we would distinguish the type of fee-shifting rule we consider here from, for example, sanctions under Federal Rules of Civil Procedure 11 and 37, intended to penalize parties and attorneys for substantively baseless claims, defenses, and for procedural misconduct.

Our analysis of how such a rule would influence damage class action litigation is inconclusive. We think it might improve the system's capacity to attract meritorious claims and resolve these claims to the benefit of class members, while driving away non-meritorious claims and discouraging collusive settlements. But these effects might be quite small, and the practical challenges of grafting such a rule onto our civil justice system might turn out to be so high that it is not worth the effort. As a consequence, we are not calling for adoption of such a rule. Nonetheless, the theoretical reasons for supposing that loserpays fee shifting with liability on the lawyer might improve the cost-benefit ratio of damage class actions seem to us to be strong enough to be worth further scholarly consideration. Our purpose here is to spur such consideration.

As a threshold matter, it seems clear that the liability for shifted attorney fees in any loser-pays system would have to rest on attorneys for the class, rather than on the class representatives or the class as a whole. We consider the delicate, although hardly novel ${ }^{57}$ suggestion of attorney liability for various reasons. First, without attorney liability on the plaintiffs' side, rigorously enforced loser-pays fee shifting would threaten to kill off class actions almost entirely, which is not our aim, as our emphasis on access along with screening makes clear. Such fee liability, if routinely imposed on named class representatives, would likely bring that necessary species close to extinction, because the representatives could hope for only a small share of the recovery while facing liability for all defense fees (even assuming continuation of the contingent fee on the plaintiffs' side, sparing the representatives from liability for fees of the class's own counsel). ${ }^{58}$ The alternative of trying to collect from the class members

57. See generally A.F. Conard, Winnowing Derivative Suits Through Attorneys Fees, 47 LAW \& CONTEMP. PROBS. 269 (Winter 1984) (considering loser-pays fee shifting in context of shareholder derivative litigation); Donald N. Dewees et al., An Economic Analysis of Cost and Fee Rules for Class Actions, 10 J. LEGAL STUD. 155 (1981) (given general Anglo-Canadian background of loser-pays fee liability, considering several alternatives for class action fee rules, including loser-pays with class counsel bearing costs and fees in event of loss); cf. Mark S. Stein, The English Rule with Client-to-Lawyer Risk Shifting: A Speculative Appraisal, 71 CHI.-KENT L. REV. 603 (1995) (suggesting, without focusing on class actions, that lawyer risk-bearing under loser-pays would be preferable to client liability); Note, Fee Simple: A Proposal to Adopt a Two-Way Fee Shift for Low-Income Litigants, 101 HARV. L. REV. 1231 (1988) (proposing loser-pays fee shifting for cases involving litigants eligible for representation funded by Legal Services Corporation, with losing attorney liable for winning party's attorney fee).

58. Our argument, although commonly made by U.S. scholars, may seem to be undercut by the apparent success of class action practice in Australia, where the "English rule" of costs-following-outcome 
poses insuperable practical problems, ${ }^{59}$ would be unfair to those who had taken no initiative to bring the action, and would likely produce opt-out stampedes.

More positive reasons for lawyer liability center around the entrepreneurial role of plaintiffs' class counsel in damage cases. They are often the effective initiators of the action, bearing the largest financial risks of anyone on the plaintiffs' side and standing to gain considerably more than any single class member. For certainty in reckoning possible exposure and to keep the defense from churning billings, there should be a cap limiting liability to the amount of reasonable fees on the plaintiffs' side. ${ }^{60}$ Thus if plaintiffs' class counsel lost on summary judgment or at trial, they would be liable for defendants' fees only up to the amount of their own reasonably calculated fees to date.

Implementing loser-pays fee shifting on the defense side of damage class action litigation would also be complicated. Currently, losing defendants may pay class counsel fees and expenses, calculated either as a share of a common fund or as a separate amount to be paid directly to class counsel in addition to whatever funds are set aside to compensate class members. However, if additional risk is to be imposed on class counsel, it would be fair for defendants also to face additional exposure, in return for the gains that they would realize under a fee-shifting regime if they prevailed. Hence, in the hypothetical loser-pays regime, courts would award a premium to class counsel, on top of the fees and expenses that would ordinarily be awarded, when they prevail. Because defense attorneys do not have an entrepreneurial stake in class action litigation, the liability for this premium would have to be borne by the defendants themselves. ${ }^{61}$

The likely incentive effects of loser-pays in the context of ordinary litigation have often been discussed, ${ }^{62}$ but the fairly standard predictions of deterrence for

prevails and class representatives bear liability for fees. See Clark \& Harris, supra note 56. Based on conversations with leading Australian attorneys, however, we understand that when victory seems quite uncertain, class counsel select for class representatives persons who have no wherewithal to pay fees and hence are not practically at risk. Australian plaintiffs' attorneys claim that to date they have not lost any cases that they have filed as class actions. Assuming this to be the case, one possible explanation is that the risk of fee shifting does indeed influence practitioners, leading them to prosecute only those claims that they are highly confident of winning.

Theoretically, in a system in which class representatives had real exposure to liability for shifted fees, we might expect to see a practice evolve of paying these representatives a substantial premium on top of their share of recovery from the common fund, to compensate them for their risk. However, as a practical matter, the size of the exposure to legal fees would be so great that the premium would have to be enormous-perhaps equal to the fees that class counsel now demand in return for the risks they undertake in prosecuting cases when recovery is uncertain.

59. See, e.g., Janet Cooper Alexander, Contingent Fees and Class Actions, 47 DePAul L. REV. 347, 354 (1998).

60. Looking to the plaintiffs' side for a fee measure might be necessary in any event, because of possible defense reluctance to reveal billings.

61. The defendants themselves tend to be good risk-bearers, and defense counsel in class actions do not play the entrepreneurial role that we see as a crucial foundation for lawyer liability on plaintiffs' side. We do not consider a one-way pro-prevailing-defendant fee shifting rule for class actions; our aim is to explore the possibilities for maintaining access to the class device while providing some screening effect, not to create a general disincentive to class actions.

62. See, e.g., Avery Wiener Katz, Indemnity of Legal Fees, in 5 ENCYClOPEDIA OF LAW AND ECONOMICS 63 (1998); Thomas D. Rowe, Jr., Predicting the Effects of Attorney Fee Shifting, 47 LAW \& 
weak claims and encouragement of strong ones may have special significance in the damage class action context. A particular problem often perceived with damage class actions is the "bet-your-company" risk, presented when a case meeting the formal (and, as we have seen, supposedly non-merits-related) criteria for class certification, but lacking strong claims on the merits, is certified. Defense counsel claim, with at least some plausibility, that the in terrorem small-odds threat of enormous liability can force substantial settlements even of quite undeserving class claims. ${ }^{63}$ Loser-pays fee shifting, tied to the outcome on the merits, could make class counsel think twice (or three times, because of their personal liability) before filing such cases,${ }^{64}$ pushing counsel away from a primary focus on settlement potential with just a preliminary peek at the merits and toward a hard and self-interested look at the merits, without the judicial involvement and speculation entailed by a merits-based factor in the certification process. On the defense side, the prospect of a fee award for a successful defense could affect marginally (but not, we think, drastically) the defendant's readiness to pursue the case to trial and-perhaps more often-the terms of settlement if one is reached. If the result were to be somewhat more trials in damage class actions when defendants regarded the claims as weak, ${ }^{65}$ we would regard that as valuable: It would develop precedent, establish an empirical basis for assessing the values of class claims, and signal attorneys that class certification does not lead inevitably to settlement. ${ }^{66}$

With class claims that are strong on both certification and the merits, the effects of a loser-pays rule might be less significant but still positive in various respects. If most certified class actions settle rather than go to trial, class counsel's likely entitlement to a shifted fee would become an element in the bargaining process, permitting somewhat larger recovery than if there were no such en-

CONTEMP. Probs. 139 (Winter 1984); Steven Shavell, Suit, Settlement, and Trial: A Theoretical Analysis Under Alternative Methods for the Allocation of Legal Costs, 11 J. LEGAL STUD. 55 (1982).

63. See supra note 21 and accompanying text. The 1998 addition of paragraph (f) to Federal Rule of Civil Procedure 23, granting courts of appeals discretion to entertain interlocutory appeals from grants and denials of class certification, could reduce the settlement pressure from arguably erroneous certifications. See FED. R. CIV. P. 23(f). But great leverage can still flow from proper certification, reviewed or not, in cases involving claims that are questionable on the merits. Loser-pays fee shifting in litigated cases would be triggered by certification but would turn on the result on the merits, giving some screening effect that is desirably tied to the strength of the merits.

64. This threat might desirably inhibit races to file first or to bring copycat class actions.

65. See A. Mitchell Polinsky \& Daniel L. Rubinfeld, Does the English Rule Discourage LowProbability-of-Prevailing Plaintiffs?, 27 J. LEGAL STUD. 141 (1998) (developing asymmetricinformation model of litigation and concluding that "when the settlement process is taken into account the English rule results in more low-probability-of-prevailing plaintiffs going to trial than the American rule."); see also Edward A. Snyder \& James W. Hughes, The English Rule for Allocating Legal Costs: Evidence Confronts Theory, 6 J.L. ECON. \& ORG. 345, 377 (1990) (finding, in study of experience under loser-pays statute applicable to Florida medical malpractice litigation, that "[f]ee shifting encourages parties to litigate rather than settle their claims"); $($ f. Avery Katz, Measuring the Demand for Litigation: Is the English Rule Really Cheaper?, 3 J.L. ECON. \& ORG. 143 (1987) (predicting increase in spending on cases brought under loser-pays).

66. Data collected by the Federal Judicial Center indicate that a significant fraction of damage class actions are dismissed on the pleadings or result in summary judgments. See WILlgING ET AL., supra note 13 , at $171 \mathrm{tbl}$. 24. But the rhetoric surrounding damage class actions implies that virtually all such suits settle. 
titlement. Any such increase in recovery, though, would probably make little difference in amounts going to class members, because plaintiffs' lawyers would earn somewhat higher fees in successful cases as a premium for bearing the risk of an adverse shift in losing actions. In cases involving large recoveries for each class member, if those cases did get class treatment, the shifted-fee aspect would become relatively less important because fees tend not to increase proportionately to stakes. Very high-stakes cases may involve multiple counsel and bloc claim referrals; in such litigation, the shifted-fee entitlement (and possible liability) might also become negotiable among the several attorneys involved on the plaintiffs' side. In sum, the additional exposure that both class counsel and defendants would face under a loser-pays fee shifting regime, measured against the already considerable risks each side faces, should have a moderate effect on each side's calculus of potential losses and gains, with mostly desirable behavioral effects.

The foregoing sketch of likely basic incentive effects of a loser-pays rule is relatively simple, at least compared with much else that takes place in the modern class actions in the United States. Beyond such basics, however, the devil would likely lie in many details, which might pose insuperable barriers to practical adoption of the loser-pays rule for the class actions that we are considering. If one shares our sense that net incentive effects could at least in theory be fairly positive, though, it is important to wrestle with the details to see if a workable approach might be framed. We proceed to discuss several such details, beyond those mentioned already (such as lawyer liability on the side of the plaintiff class), seeing some problems as solvable while recognizing that the obstacles are formidable. The issues and obstacles arise in part from the intricacies of our legal system and the difficulties of introducing a relatively novel approach, as well as concerns for specific contexts such as civil rights cases, rather than from any fundamental unsuitability of loser-pays rules for class actions generally. Indeed, if those in other nations with loser-pays rules who are considering introduction or amendment of class actions can accept some form of the entrepreneurial role of the plaintiffs' class action attorney in the United States, lawyer liability for shifted fees could actually make the device more viable than under alternative versions of loser-pays. ${ }^{67}$

A threshold issue, assuming the implantation of a loser-pays rule into a system generally not following that approach, is how far the rule should extendto all actions filed seeking class certification? Only to certified class actions? Only to particular types of class actions? Our initial inclination is to say that it should extend only to certified class actions seeking monetary relief at least in part, and to which existing one-way pro-prevailing-plaintiff fee-shifting statutes such as the Civil Rights Attorney's Fees Awards Act ${ }^{68}$ do not already apply. As skeptics of broader loser-pays approaches, we would not seek to extend loserpays rules beyond the context in which we see screening as most warranted: the

67. See generally Dewees et al., supra note 57 .

68. 42 U.S.C. $\$ 1988$ (b) (Supp. IV 1998). 
class context in which the attractiveness of filing weak claims and their settlement value can be greatest, when the system greatly enhances the threat by conferring class status. Imposing some price in return for that leverage (and as a deterrent to its misuse) could be both fair and functionally desirable. Fee liability would be triggered only by class certification and would not extend to cases never certified (even despite efforts to get them certified) or decertified before judgment, although other bases of fee liability, such as statutory entitlements and rule sanctions, could still exist. The calculation of a fee to be shifted to the prevailing plaintiffs' side would probably — if regrettably — have to be by the rate-times-hours lodestar method ${ }^{69}$ because shifting a percentage-based fee liability is very different from taking a percentage out of plaintiffs' recovery. To assure adequate compensation for plaintiffs' counsel, courts could, of course, also approve percentage awards from the class recovery.

Limiting the form of fee shifting we are considering to damage class actions makes sense to us because injunctive and declaratory class actions do not pose (at least not to the same degree) the in terrorem threats of a certified damage class. (Such a limit would, however, pose borderline issues in hybrid and limited-fund cases that would need further consideration, and might involve difficult allocation questions. ${ }^{70}$ ) Injunctive and declaratory actions may alsosomewhat more often than damage claims-involve efforts at law reform, and we would want to avoid, if possible, the inhibiting effects of a loser-pays rule in such cases.

This observation leads to a further issue: How would a loser-pays rule for damage class actions relate to existing one-way pro-prevailing-plaintiff fee rules in many federal civil rights actions and other types of cases, in which Congress and state legislatures have sought to rely on enforcement of public law by "private attorneys general" $?^{71}$ Limiting the rule's application to certified class ac-

69. See MANUAL FOR COMPLEX LitigAtion, supra note 39, § 24.13 ("[I]n a statutory fee case ... the lodestar is the appropriate method." (footnote omitted)).

70. Some such issues arise already as to whether actions in part for damages and in part for prospective relief should be regarded as (b)(2) actions without opt-out rights, or if there should be opt-out rights as to the aspects involving possible money relief. See, e.g., Jefferson v. Ingersoll Int'l Inc., 195 F.3d 894, 897-98 (7th Cir. 1999) (casting doubt on use of Federal Rule of Civil Procedure 23(b)(2) to certify non-opt-out class when damages are in issue); Thomas v. Albright, 139 F.3d 227, 234-35 (D.C. Cir. 1998), cert. denied, 525 U.S. 1033 (1998), and cert. denied sub nom. Fields v. Albright, 525 U.S. 1016 (1998) (discussing circumstances under which opt-outs should be allowed when money relief is sought in class actions also involving injunctive relief). Some guidance might be gained from cases facing these sorts of borderline questions in other contexts. The guiding principle, however, should remain that fee shifting was justified by the leverage created by the threat of enhanced monetary liability from class actions for money relief.

Another somewhat technical issue whose resolution seems more clear-cut is whether defendants should be able to use formal offers of judgment of the sort allowed under Federal Rule of Civil Procedure 68 to try to cut off their liability for a plaintiff class's post-offer fees, and even to claim entitlement to their own post-offer fees if the offer is not accepted and the eventual result is not better than the offer. We think not, because offer rules presume autonomy in deciding whether to accept the offer, yet courts must approve class action settlements. It would be unfair to impose consequences on class counsel who sought to accept the offer only to have the court refuse approval. See 13 MOORE'S FEDERAL PRACTICE $\$ 68.03[3]$, at $68-13$ to -14 (3d ed. 2000).

71. See, e.g., Civil Rights Attorneys' Fees Awards Act, 42 U.S.C. $§ 1988$ (Supp. IV 1998). 
tions seeking monetary relief could reduce this problem. But many discrimination cases, for example, involve claims for monetary relief on behalf of plaintiff classes, leaving open the question whether loser-pays would conflict intolerably with lawmakers' intent to encourage such claims by favoring them with the oneway rule. Loser-pays is undeniably less favorable to plaintiffs than the existing, mostly one-way approach followed in federal civil rights cases. ${ }^{72}$ Further, in their research for the class action study, RAND's analysts found little empirical evidence of concern about abuse of the device in civil rights cases. In any realworld consideration of loser-pays for class actions, Congress or state legislatures $^{73}$ might therefore be well advised to make an exception for civil rights and similar cases. At the very least, judicial discretion to reduce or deny a fee shift might need to be an element of a loser-pays system.

This return to the theme of risk bearing leads to a further question: Should attorneys liable for shifted fees be able to insure against that risk, and thus dilute the effect of their exposure? We would not be inclined to try to impose any bans on such further risk-shifting if the market responded to the new fee risk by offering insurance. Attorney liability for shifted fees would broaden the present risk-bearing insurer role of contingent-fee counsel, and we see no reason to try to forbid a choice between self-insurance and market-provided insurance. Insurers have their own incentives to monitor risks taken by their insureds. Moreover, insurance for clients against the loser-pays risk, which was recently created by the narrowing of legal aid, appears to be working efficiently in Britain. $^{74}$ In addition, the availability of insurance might allay the concern from the added risk of fee liability that loser-pays with attorney liability could result in the concentration of plaintiffs' class actions in fewer and larger firms, thereby reducing the ability of smaller classes and firms to use the device.

Other issues of concern are the incentives created by a distinction making fee liability and entitlement turn on class certification, and the forum-choice effects in our federal system if loser-pays were the rule for money-relief class actions in some systems but not others. Claims that seemed somewhat weak on the merits might still be filed if they were large enough, but we would expect them to be filed less often in class form. That channeling could make for desirable testing of the claims in individual litigation, with efforts at class processing

72. Empirical research done in civil rights cases suggests that "attorney fee statutes may have less of an effect on filing rates than is commonly believed." Stewart J. Schwab \& Theodore Eisenberg, Explaining Constitutional Tort Litigation: The Influence of the Attorney Fees Statute and the Government as Defendant, 73 CORNELl L. REV. 719, 780 (1988). The down-side risk created by the possibility of adverse shifts under a loser-pays rule, however, might be more effective as a deterrent than the prospect of a favorable shift is as an inducement.

73. The substantive implications of loser-pays are such that we would not suggest its consideration by non-legislative procedural rule-makers, who in the federal system may not "abridge, enlarge or modify any substantive right." 28 U.S.C. \$ 2072(b) (1994).

74. See Geoffrey Woodroffe, Loser Pays and Conditional Fees-An English Solution?, 37 WASHBURN L.J. 345, 355-56 (1998). 
following later if the claims met with success. ${ }^{75}$ For claims that appeared strong on the merits but questionable for class certification, courts would need to remain vigilant about the procedural standards to check the temptation to take advantage of a likely favorable shift in a certified action.

As for problems arising from forum choices between jurisdictions with and without the rule, they could be less severe than one might initially think. Plaintiffs seeking to avoid loser-pays should be those with weaker claims, so that systems without the rule would become magnets for such cases. If the rule appeared to be working well in systems that had it and drew class actions with stronger claims, the desire to avoid being a dumping ground could provide an incentive to adopt the rule. Divergence would provide for some generally useful comparative experience, and one form of the rule that could avoid or considerably reduce disparity would be to apply it to federal-question cases (other than those subject to one-way fee regimes ${ }^{76}$ ), whether filed in state or federal court.

\section{IV}

\section{CONCLUSION}

Improving the court system's ability to screen out non-meritorious damage class actions while assuring access for meritorious claims turns out to be enormously difficult. But failure to address this challenge will lead to the continued erosion of support for representative litigation as a means of securing compensation for modest harms imposed on widely dispersed victims, and enhancing enforcement of consumer protection statutes. To protect access to the courts, we need to ensure that those who gain access have legitimate purposes and that these purposes are properly served.

Raising the threshold for damage class action certification has the apparent virtues of directness and simplicity. But these virtues are illusory. It is difficult to distinguish among meritorious and non-meritorious claims when they are first filed. The size of underlying claims does not denote their merit, the nature of the ultimate remedy is unknown, and the costs of process are highly uncertain. Determinations of substantive merit made without the procedural safeguards of a summary judgment proceeding are more likely to reflect the decisionmakers' subjective judgments of the value of damage class actions than an objective assessment of the merits of the case before them. Relying on potential class members' decisions to come forward as a measure of merit is similarly perilous. If representative litigation is to survive as a real remedy for widely dispersed harms, it must allow for the possibility that at the inception of litigation only a few more knowledgeable and more interested members of the class will step forward on behalf of others. Requiring class members to opt in re-

75. See generally Francis E. McGovern, Resolving Mature Mass Tort Litigation, 69 B.U. L. REV. 659 (1989).

76. See supra text accompanying note 70 . 
creates the very obstacle to litigation that representative litigation seeks to overcome.

Adopting a fee-shifting regime, with liability on the plaintiff's side borne by class counsel, holds out theoretical hope of improving the cost-benefit ratio of damage class actions by re-calibrating the incentives of class counsel to file damage class actions, of defendants to contest them, and of class counsel and defendants to negotiate settlements that properly reflect the merits of the underlying claims. But there are huge practical problems to overcome in grafting a fee-shifting rule onto our legal process, with its presumption that each side bears its own costs. And the shift in incentives might be modest, and not worth the problems attendant on implementation. The gain to plaintiff class members in successful cases could be little or none, given the risk premium that class counsel would merit for bearing the risk of liability in case of defeat. The screening effect from the rule could be somewhat marginal, given the risk of no recovery for a losing case that currently exists under the contingent-fee regime; the screening goal might be better achieved with fewer inhibitions to access by different means discussed above and by others. ${ }^{77}$ Screening might also deter worthwhile novel theories, in addition to weak claims, and any fee-shifting regime comes with significant transaction costs in fee calculation, litigation over possible exceptions, and fee amounts. Furthermore, loser-pays fee shifting with lawyer liability on the plaintiffs' side would not address all of the agency problems of conflict between interests of the class and its counsel. Indeed, it could create some new forms of such conflicts that would need to be addressed-although these obstacles should not be insuperable. ${ }^{78}$

This complex mix of some promise along with major difficulties leaves us able to conclude only that further scholarly investigation of the incentive effects of such fee-shifting on damage class actions would be useful. U.S. decisionmakers might also usefully examine the experiences of other countries, such as Australia, that have recently incorporated damage class action rules into a civil litigation regime that provides for loser-pays fee shifting with liability on the plaintiffs' side borne by class representatives. But at the moment, we would not put our money on fee-shifting as the solution to the many dilemmas posed by damage class actions.

Calling on judges to use their existing authority to review and approve settlements and fee award requests more vigorously is more mundane than other proposals that have been put forward, and some have asserted that it is doomed to failure. ${ }^{79}$ But based on qualitative evidence from the RAND study, we believe that judges could improve the cost-benefit ratio of damage class actions

77. See, e.g., Bruce Hay \& David Rosenberg, "Sweetheart" and "Blackmail" Settlements in Class Actions: Reality and Remedy, 75 NOTRE DAME L. REV. 1377 (2000) (discussing fee-calculation and sample-trial approaches aimed at creating incentives for settlements at levels reflecting the likely merits of class claims).

78. See Stein, supra note 57, at 618-23 (discussing lawyer-client conflicts in the settlement process under the regime of lawyer liability for shifted fee).

79. See, e.g., Coffee, supra note 36. 
considerably by regulating class action practice more strictly. Such a strategy requires educating judges to understand the special role they have to play in damage class actions, and providing them with specific guidance and resources to carry out their responsibilities. ${ }^{80}$ It may also require finding a way of restricting attorneys' ability to shop for judges who are willing to approve nonmeritorious settlements and to award fees out of proportion to what class counsel have achieved on behalf of their clients. But over the long run, such efforts just might be worth it.

80. As we write this, the Civil Rules Advisory Committee is considering just these sorts of changes. See Rosenthal, supra note 9. 